\title{
Human papillomavirus 16 DNA in NIH3T3 cells transformed by colonic cancer cellular DNA
}

\author{
Jhy-Young Cheng, Ching-Liang Meng, Chung-Faye Chao, Shun-Der Gau, Jih-Chang Lin
}

\begin{abstract}
Human papillomavirus (HPV) 16 DNA is closely associated with human cancers. It has been identified as an aetiological agent in cervical cancers and, recently, in colonic neoplasms. To further understand the role of HPV 16 DNA in colorectal carcinogenesis, NIH3T3 cells were transformed with high molecular weight DNA from colonic cancer cells and the expression of HPV 16 DNA detected. Both human Alu and HPV 16 DNA sequences were found in the type II foci of CC-M2T cells by Southern blot hydribisation. Additionally, $100 \%$ tumorigenicity in nude mice was seen. This study shows the transfection of HPV DNA from colonic cancers into NIH3T3 mouse cells and suggests that HPV type 16 might be associated with the malignant transformation of colonic cells.

(Gut 1993; 34: 1710-1713)
\end{abstract}

Colorectal carcinoma ranks second only to lung cancer in men and to breast cancer in women in the United States. ${ }^{1}$ The specific carcinogens, however, that cause the colorectal cancers in humans remain unknown. Human papillomavirus (HPV) have been reported to be associated with the genital tract ${ }^{2-5}$ and extragenital tumours $^{6-8}$ in previous studies. Those works have shown that HPVs are associated with premalignant and malignant lesions of the stratified squamous epithelium. Nevertheless, reports of HPV infection in the cancer of the columnar epithelium are few. Recently, Kirgan et $a l^{910}$ have shown HPV antigen and genome in colon neoplasms. We have also found HPV DNA sequences in three cell lines of colorectal cancer from Chinese subjects. " These findings might suggest the correlation of HPV with cause of colorectal cancers.

It is uncertain whether HPV DNA acts as a causal agent or a causal passenger in colorectal carcinogenesis. Therefore, the biological activity of HPV DNA in cells has been studied to investigate this issue. ${ }^{12-17}$ We extracted the cellular DNA of human colonic cancers to transform NIH3T3 cells and investigated its possible role in colorectal carcinogenesis.

\section{Materials and methods}

CELLS

NIH3T3 cells were cultured in Dubecco modified Eagle's medium (DMEM) supplemented with $10 \%$ calf serum (Gibco Laboratories, Scotland) ${ }^{13}$ CC-M2, CC-M3, CC-M4 cell lines were grown in RPMI (Roswell Park Memorial Institute) - 1640 (J R Scientific, Inc,
Woodland, CA, USA) medium with $10 \%$ fetal calf serum (Gibco) and cultured as previously described. ${ }^{18}$

\section{TRANSFECTION}

High molecular weight DNA was extracted from CC-M cells as in previous studies. ${ }^{1}$ All DNA transfers were done by calcium phosphate precipitation. ${ }^{19}$ In brief, about $20 \mu \mathrm{g}$ cellular DNA in $0.5 \mathrm{ml}$ of $0.5 \mathrm{M} \mathrm{CaCl}_{2}$ was mixed with $0.5 \mathrm{ml}$ of $50 \mathrm{mM}$ hydroxyethylpiperazine-ethanesulphonic acid (HEPES) ( $\mathrm{pH} 7 \cdot 1$ ) and $70 \mathrm{mM}$ sodium phosphate, and then agitated with a gentle stir. At room temperature, calcium phosphate was precipitated from this DNA solution in 30 minutes. Then, the solution was added to a $100 \mathrm{~mm}$ Petri dish containing $5 \times 10^{5}$ NIH3T3 cells in $10 \mathrm{ml}$ DMEM and $10 \%$ calf -serum. Another dish, free of DNA solution, was used as a control culture. The cells were incubated for 14 hours in a humidified atmosphere with $5 \% \mathrm{CO}_{2}$ in air at $37^{\circ} \mathrm{C}$. The DNA solution was then removed and $10 \mathrm{ml}$ DMEM containing $10 \%$ calf serum was added. The medium was changed twice weekly. After 14 days' incubation, the number of transforming foci was obtained from the triplicate assays and the foci were harvested by the cloning cylinder procedure.

According to the description by Reznikoff et $a l,{ }^{20}$ three types of transformed cells were classified. Type I foci, which was regarded as not significant, consisted of condensed cells with little or no cellular overlap. Type II foci were formed of piled up cells that stained darkly, but had comparatively smooth edges. Type III foci had by far the most unusual morphology: highly condensed, heavily piled upon one another, and criss crossed at the edges of the focus.

\section{DNA EXTRACTION}

Total cellular DNA from each focus was extracted from these cells and from the normal epithelium of the colon, which was used as a normal control by the method previously described. ${ }^{21} 22$ Briefly, DNA was extracted and incubated with sodium dodecyl sulphate (SDS) and RNase at $37^{\circ} \mathrm{C}$ for three hours. Subsequently, proteinase $\mathrm{K}$ was added and incubated again overnight. Cellular DNA was then extracted with phenol/chloroform/ isoamylalcohol $(25: 24: 1)$, and dialysed with TE (10 mM TRIS-HCl, $1 \mathrm{mM}$ EDTA, pH 8.0) buffer solution. After centrifugation $(1000 \mathrm{~g}$ at $4^{\circ} \mathrm{C}$ for 20 minutes) the DNA in the supernatant was precipitated by the addition of ethanol. Precipitated nucleic acids were then washed with $70 \%$ ethanol and dried in the air. The absorbance of DNA at $260 \mathrm{~nm}$ was determined by a DU-50 
series spectrophotometer (Beckman Instruments, Inc, CA, USA) and compared with the absorbance at $280 \mathrm{~nm}$. The DNA absorbance ratio ranged from $1 \cdot 8$ to $2 \cdot 0$.

\section{SOUTHERN BLOT HYBRIDISATION}

Filter hybridisation was carried out as described by Southern. ${ }^{23}$ Briefly, each DNA was cleaved with the restriction enzyme EcoR I and then electrophoresed in 1\% agrose gel. After staining with ethidium bromide, the DNA was denatured in situ and transferred to nitrocellulose filter paper (Bio-Rad Laboratories, Richmond, CA, USA) with an electroblot apparatus (Bio-Rad). To show the presence of human genes in mouse cells, the filters were hybridised with a human DNA marker, Alu family sequences, ${ }^{24}$ with specific activity ranging $2 \times 10^{8}$ to $2 \times 10^{9} \mathrm{cpm} / \mu \mathrm{g}$ in high stringency conditions, then washed several times at $55^{\circ} \mathrm{C}$, and finally exposed to an $x$ ray film by an autoradiographic method at $-70^{\circ} \mathrm{C}$. In this assay, normal NIH3T3 cells and human leucocytes were used, as negative and positive controls, respectively. After removal of Alu probes, the filters were also hybridised to nick translated ${ }^{32} \mathrm{P}$-labelled HPV DNA $\left(2 \times 10^{8}\right.$ $\mathrm{cpm} / \mu \mathrm{g})$ under stringent conditions $(50 \%$ formamide, $10 \%$ dextran sulphate, $5 \times$ Denhardt's solution, $1 \%$ SDS- $1 \mathrm{M} \mathrm{NaCl}, 50 \mathrm{mM}$ TRIS-HCl, pH 7.4, $500 \mu \mathrm{g} / \mathrm{ml}$ depurinated salmon sperm DNA) at $42^{\circ} \mathrm{C}$ for 24 hours. Filters were washed twice in $2 \times \mathrm{SSC}(1 \times \mathrm{SSC}$ is $0.15 \mathrm{M}$ $\mathrm{NaCl}$ plus $0.015 \mathrm{M}$ sodium citrate) containing $0.5 \%$ SDS for 30 minutes at room temperature and then in $0.1 \times S S C$ containing $0.1 \%$ SDS at $50^{\circ} \mathrm{C}$ for 30 minutes before autoradiography, Filters were dried and exposed to XAR 2 film (Eastman Kodak Co, Rochester, NY, USA) with an enhancing screen at $-70^{\circ} \mathrm{C} .{ }^{25} \mathrm{DNA}$ molecular weight marker was obtained from Bethesda Research Laboratories (Gaithersburg, MD, USA).

\section{TUMORIGENECITY}

Transformed cells were subcutaneously injected into bilateral flanks of six adult female BALB/c nude mice. About $5 \times 10^{6}$ cells were injected per site. Within one to two months, the newly grown tumours were removed and their representative sections were stained with haematoxylin and eosin.

\section{Results}

TRANSFORMATION OF NIH 3 T3 CELLS

The transforming activity of DNAs, which induced morphological transformation of

Transforming efficiency and tumorigenecity of $\mathrm{NIH}-3 \mathrm{~T} 3 \mathrm{cells}$ transformed by CC-M cellular DNAs

\begin{tabular}{|c|c|c|c|c|}
\hline \multirow{2}{*}{$\begin{array}{l}\text { Human } \\
\text { domor } \\
D N A\end{array}$} & \multicolumn{3}{|l|}{ Foci/ $\mu g$ DNA } & \multirow{2}{*}{$\begin{array}{l}\text { Tumorigenecity } \\
\text { (no of tumours/ } \\
\text { no of injections) }\end{array}$} \\
\hline & Type I & Type II & Type III & \\
\hline CC-M2 & $0.017(1 / 60)$ & $0 \cdot 25(15 / 60)$ & 0 & $6 / 6$ \\
\hline CC-M3 & $0.033(2 / 60)$ & 0 & 0 & $0 / 6$ \\
\hline CC-M4 & $0.017(1 / 60)$ & 0 & 0 & $0 / 6$ \\
\hline None & 0 & 0 & 0 & $0 / 6$ \\
\hline
\end{tabular}
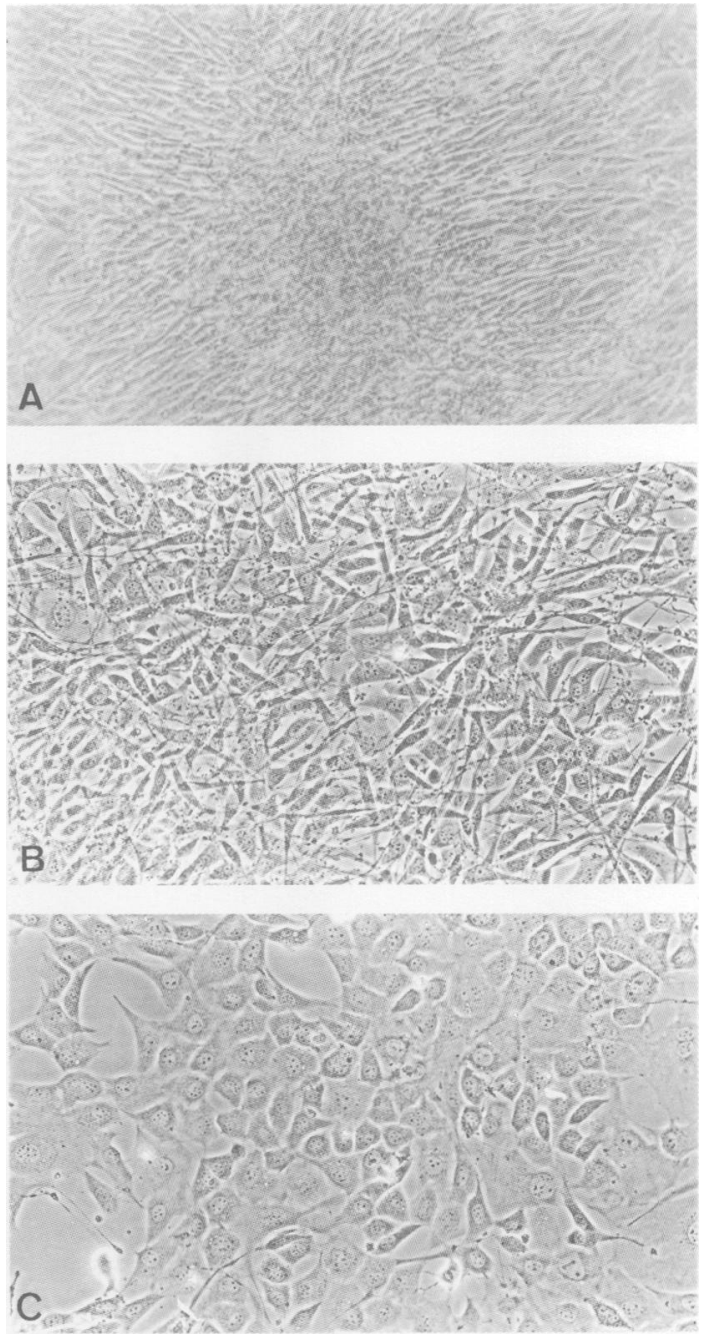

Figure 1: Phase contrast of micrographs of $(A)$ morphological appearance of NIH-3T3 cells transformed with the high molecular weight DNA of CC-M2 cells, original magnification $\times 100$ and $(B)$ longterm culture of $C C-M 2 T$, original magnification $\times 200(C)$ typical uniformly flat morphology of NIH-3T3 cells, original magnification $\times 200$.

NIH3T3 fibroblasts in the cancer cells were estimated. The Table shows that only high molecular DNA isolated from CC-M2 cells was able to induce type II transforming foci of which the transforming efficiency was $\mathbf{0} \cdot 25$ focus per $\mu \mathrm{g}$ of DNA. In contrast with type II focus, the type I ranged from $0 \cdot 017$ to $0 \cdot 033$. These results indicate that CC-M2 cells contain activated transforming genes. The morphology of type II focus was comprised of tightly packed cells, which were extensively piled upon one another and had comparatively smooth edges (Fig 1A). These cells, however, showed a criss cross appearance after longterm cultivation (Fig 1B). They were significantly different from nontransformed NIH3T3 cells, which showed contact inhibition of cell growth, strong cell to substrate adhesion, and uniformly flat morphology (Fig 1C).

HPV DNA IN TRANSFORMED CELLS

Cell lines, derived from transformed foci that were induced by CC-M2, CC-M3, CC-M4, were designated as CC-M2T, CC-M3T, CC-M4T respectively. All transformed cell lines were examined by Southern blot hybridisation. The 


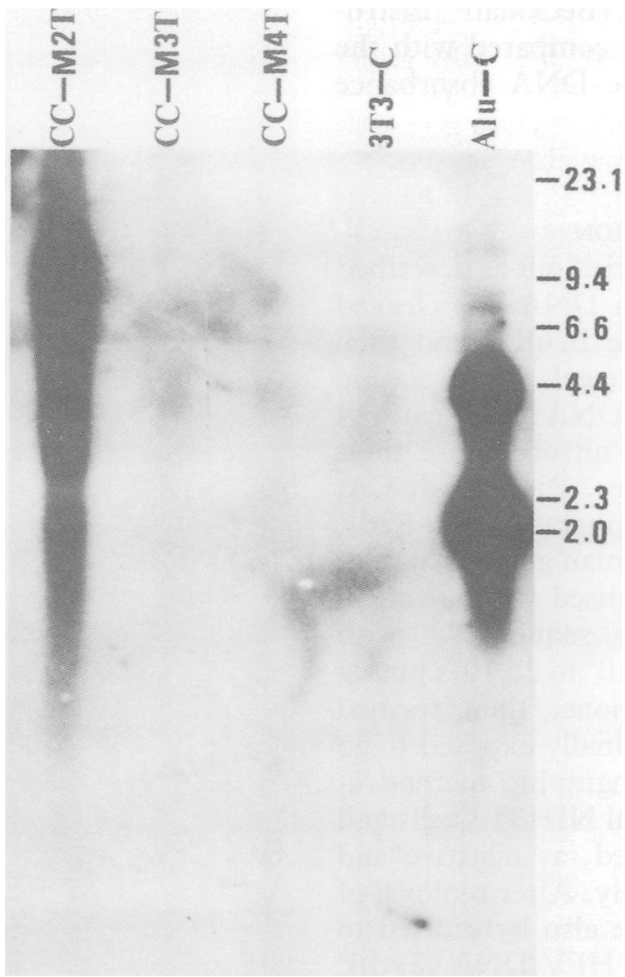

Figure 2: Southern blot analysis of human Alu family sequences in CC-M2T transfected by $C C-M 2$ cellular DNA and control cells. Non-transfected and positive controls: 3T3-C and Alu-C.

results showed that all type II foci of CC-M2T cells were the only positive foci in the DNA hybridisation assay of human Alu family sequences (Fig 2). These results show that human DNAs integrate only into the type II foci of CC-M2T. CC-M2T that contained Alu sequences was also positive in the hybridisation with ${ }^{32} \mathrm{P}$-labelled HPV-16 DNA sequences (Fig 3). Under highly stringent conditions, two important HPV-16 related DNA bands of 7.9 and $2 \cdot 2 \mathrm{~Kb}$ were found in CC-M2T cells. Other cell lines, however, in this assay were all negative.

\section{TUMORIGENECITY}

The Table shows the results of tumour induction. Tumours developed only from the CC-M2T cell line within six weeks. The tumorigenecity of CC-M2T in nude mice was $100 \%(6 / 6)$. The tumours were then removed to establish another cell line for future studies. The histological examination of these tumours showed a fibrosarcoma like picture.

\section{Discussion}

Human papillomavirus has been shown to play a causal part in cervical neoplasia..$^{2-5}$ It has also been found closely associated with human extragenital cancers. ${ }^{6-8}$ Few reports, however, have shown the relation between HPV and colonic cancers. Kirgan et $a l^{910}$ found that colonic neoplasms contain both HPV antigen and viral genome. Nevertheless, Southern blot is a well known standard technique in DNA hybridisation. Therefore, we have shown the expression of HPV-16 and HPV-18 DNA in colonic cancer

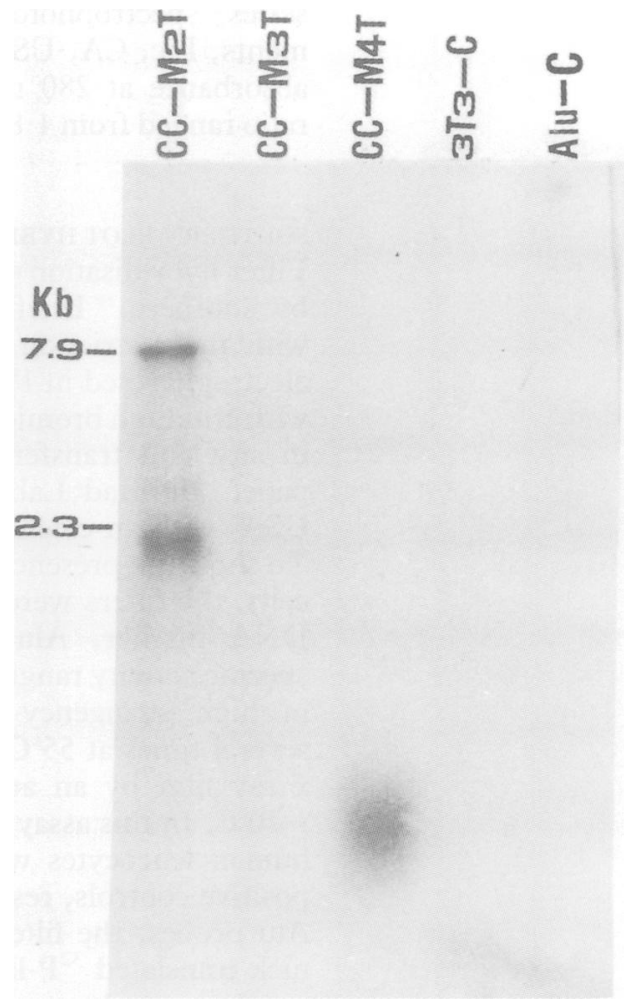

Figure 3: Southern blot analysis of HPV 16 DNA sequences in the same nitrocellulose filter as Figure 2.

(CC-M) cell lines by Southern blot hybridisation. " From this study, we believe that HPV may play an important part in colorectal carcinogenesis. Although a number of studies have described the HPV transforming activity in the transformation of normal cells, ${ }^{12-16}$ the carcinogenic mechanisms of HPV is not yet completely understood. Also, activated transforming genes in some human tumours have been detected by DNA transfection. ${ }^{26-28}$ There is still not one study concerning the transmissible condition of HPV DNA in colonic cancers. To identify the HPV transfection of human tumour cell lines to normal mouse cells, we have shown the Alu sequences of human DNA marker in the genome of NIH3T3 transformants, although CC-M2 was the only cell line that transfected successfully. Our transfection rate was higher compared with previous reports ${ }^{26}$ Perucho et al $^{26}$ have shown that only five of 21 human tumour cell lines contain a gene or genes capable of transforming mouse cells. In Krontiris and Cooper's ${ }^{27}$ series, only two of eight human tumour cell lines and none $(0 / 13)$ of primary tumours can transform NIH3T3 cells. The low efficiency of transformation with human tumour DNA may be attributed to several reasons. Firstly, the molecular heterogeneity of tumours with the same origin, histological type, and differentiated level. ${ }^{27}{ }^{29}$ In other words, cell lines derived from tumours of the same tissue may contain two different transforming genes. ${ }^{26}$ Secondly, the long latency in the transformation of rodent cell lines by HPV. ${ }^{13}$ This suggests that longer than 14 days' incubation is required to obtain transforming foci. Thirdly, the lack of cooperative activated oncogenes. Matlashewski ${ }^{14}$ has described two groups of genes that are required in the morphological transformation of normal 
primary cells in vitro. One group is the establishing genes such as myc, Ela and the other is the transforming genes including ras and polyoma middle $\mathrm{T}$ genes. He has also shown that activated ras gene is required in the morphological transformation of HPV-16 DNA. In other words, negative cell lines may lack some genes capable of transforming NIH/3T3 cells or contain a set of genes that could transfer 3T3 cells, but at an efficiency of focus induction too low for detection. ${ }^{26}$ Fourthly, the size of transforming genes is too large at transfer. Perucho ${ }^{26}$ and Wigler $e t a l^{30}$ have shown that the efficiency of transformation may be subject to the size and nature of the transforming fragment.

Dürst ${ }^{31}$ has reported that the sequences of papillomavirus may be integrated near the cellular oncogenes in some cervical carcinomas. These activated cellular oncogenes by HPV DNA may participate in the malignant transformation of cervical cells. Interestingly, in our study, all type II foci of CC-M2T cells contained HPV DNA sequences and showed a $100 \%(6 / 6)$ tumorigenecity in nude mice. The tumour cells grown from nude mice were also found to have HPV DNA sequences (unpublished data). This suggests that HPV may be an active gene in carcinogenesis and thus does not lose in in vivo passage. HPV-16 DNA has been detected in all CC-M colonic cancer cell lines. " Moreover, HPV genomes was found in $43 \%$ of colonic carcinomas and none in normal mucosa (unpublished data). In this study, we have exclusively shown the transfection of HPV-16 DNA from colonic cancer cells to NIH3T3 cells. Because HPV-16 DNA is known to activate cellular oncogene ${ }^{31}$ and is closely associated with malignant transformation, ${ }^{1314}$ these findings suggest that an association of HPV-16 DNA with the multistep development of colorectal cancers may exist. As in the report by Reznikoff $e t a l,{ }^{20}$ all the type I foci in this study had a nontumorigenic character in vivo and were considered to have no transforming response.

In conclusion, the HPV DNA of colonic cancer cells can integrate and induce neogrowth in mouse cells. These data suggest that HPV-16 may play an active part in colorectal carcinogenesis and may not be simply a casual DNA in transformed cells. This study provides valuable insight into the association of HPV DNA with colonic cancers. Further investigations into the mapping of HPV integration sites and nearby activated oncogene will be very helpful in better understanding colorectal carcinogenesis.

This study was presented at the 45th General Scientific Meeting in September 1991, Surgical Association, Taipei, Taiwan. Supported by a grant from the National Science Council (NSC 81-0412-B-016-48), Taiwan, Republic of China.

We thank Dr K R Yu for his technical assistance and Ms Jean Chuang for proof reading.

1 Cancer Statistics. CA 1985; 35: 19-35.

2 McCane DJ. Prevalence of human papillomavirus type 16 DNA sequence cervical intraepithelial neoplasia and invasive carcinoma of the cervix. Br $\mathcal{F}$ Obstet Gynaecol 1986; 92: 1101-5.

3 Lorincz AT, Temple GY, Kurman RJ, Bennett Jenson A, Lancaster WD. Oncogenic association of specific human papillomavirus types with cervical neoplasia. 7 Natl Cancer Inst 1987; 79: 671-7.

4 Ostrow RS, Manias DA, Clark BA, Okagaki T, Twiggs LB, Faras AJ. Detection of human papillomavirus DNA in invasive carcinoma of the cervix by in situ hybridization. Cancer Res 1987; 47: 649-53.

5 Tase T, Okagaki T, Clark BA. Human papillomavirus types and localization in adenocarcinoma and adenosquamous carcinoma of the uterine cervix: A study by in situ DNA hybridization. Cancer Res 1988; 48: 993-8.

6 Brandsma JL, Steinberg BM, Arrand AL, Winkler B. Presence of human papillomavirus type 16 related sequences in verrucous carcinoma of the larynx. Cancer Res 1986; 46: 2185-8.

7 Ostrow RS, Manias DA, Fong WJ, Zachow KR, Faras AJ. A survey of human cancer for human papillomavirus DNA A survey of human cancer for human papilloma

8 Bejui-thivolet $\mathrm{H}$, Liagre N, Chignol MC, Chardonnet $\mathrm{Y}$ Patricot LM. Detection of human papillomavirus DNA in squamous bronchial metaplasia and squamous cell carcinomas of the lung by in situ hybridization using biotinylated probes in paraffin-embeded specimens. Huma Pathol 1990; 21: 111-6.

9 Kirgan D, Manalo P, McGregor B. Immunohistochemical demonstration of human papillomavirus antigen in human colon neoplasms. I Surg Res 1990; 48: 397-402.

10 Kirgan D, Manalo P, Hall M, McGregor B. Association of human papillomavirus and colon neoplasms. Arch Surg 1990; 125: 862-5

11 Cheng J-Y, Meng C-L, Chao C-F, Gau S-D, Lin J-C. Human papillomavirus type-related DNA and c-myc oncogene papilomavirus type-related DNA and c-myc oncogene 34: 469-74.

12 Watts SL, Phelps WC, Ostrow RS, Zachow KR, Faras AJ. Cellular transformation by human papillomavirus DNA in vitro. Science 1984; 225: $634-6$.

13 Yasumoto S, Burkhardt AL, Dominger J, Dipaolo JA. Human papillomavirus type 16 DNA-induced malignant transformation of NIH3T3 cells. $\mathcal{F}$ Virol 1986; 57: 572-7.

14 Matlashewski G, Schneider J, Banks L, Jones N, Murray A, Crawford $L$. Human papillomavirus type 16 DNA EMBO F 1987; 6: 1741-6.

15 Kaur P, McDougall JK. Characterization of primary human keratinocytes transformed by human papillomavirus type 18. ₹ Virol 1988; 62: 1917-24.

16 Pecoraro G, Lee M, Morgan D, Dendi V. Evolution of in vitro transformation and tumorgenesis of HPV 16 and HPV 18 immortalized primary cervical epithelial cells. Am $\mathcal{F}$ Pathol 1991; 138: 1-8.

17 Blanton RA, Perez-Reyes N, Merrick DT, McDougall JK. Epithelial cells immortalized by human papillomaviruses have premalignant characteristics in organotypic culture. Am f Pathol 1991; 138: 673-85.

18 Cheng J-Y, Meng C-L, Lin J-C, Tzeng CC, Chin LT, Shen KL. Characterization of four newly established human colorectal adenocarcinoma cell lines from Chinese patients. colorectal adenocarcinoma cell

19 Wigler M, Pellicer A, Silverstein S, Axel R, Urlaub G, Chasin L. DNA-mediated transfer of the adenine phosphoribosyl L. DNA-mediated transfer of the adenine phosphoribosyl transferase locus into man

20 Reznikoff CA, Brankow DW, Heidelberger C. Establishment and characterization of a cloned line of $\mathrm{C} 3 \mathrm{H}$ mouse embryo cells sensitive to post-confluence inhibition of cell division. Cancer Res 1973; 33: 3231-8.

21 Gross-Bellard M, Oudet P, Chambon P. Isolation of high molecular weight DNA from mammalian cells. Eur $\mathcal{f}$ Biochem 1973; 36: 332-8.

22 Yee C, Krishnan-Hewlett I, Baker CC, Schlegel R, Howley PM. Presence and expression of human papillomavirus sequences in human cervical carcinoma cell lines. $A m \mathcal{F}$ Pathol 1985; 119: 361-6.

23 Southern EM. Detection of specific sequences among DNA fragments separated by gel electrophoresis. F Mol Biol 1975; 98: 503-17.

24 Jelinek WR, Toomey TP, Leinwand L, Duncan CH, Biro PA, Choudary PV. Ubiquitous, interspersed repeated sequences in mammalian genomes. Proc Natl Acad Sci USA 1980; 77: $1398-402$.

25 Woodworth CD, Bowden PE, Doniger J, Pirisi L, Barnes W, Lancaster WD, et al. Characterization of normal human exocervical epithelial cells immortalized in vitro by papillomavirus types 16 and 18 DNA. Cancer Res 1988; 48: 4620-8.

26 Perucho M, Goldfarb M, Shimizu K, Lama C, Fogh J, Wigler $M$. Human-tumor-derived cell lines contain common and different transforming genes. Cell 1981; 27: 467-76.

27 Krontiris TG, Cooper GM. Transforming activity of human tumor DNAs. Proc Natl Acad Sci USA 1981; 78: 1181-4.

28 tumor DNAs. Proc Natl Acad Sci USA 1981; 78: 1181-4. genes of carcinomas and neuroblastomas introduced into genes of carcinomas and neuroblastomas
mouse fibroblasts. Nature $1981 ; 290: 261-4$.

29 Pillai R, Reddiar KS, Balaran P. Oncogene expression and ora cancer. F Surg Oncol 1991; 47: 102-8

30 Wigler M, Raymonds S, Sim GK, Wold B, Pellicer A, Lacy E et al. Transformation of mammalian cells with genes from procaryotes and eucaryotes. Cell 1979; 16: 777-85.

31 Dürst M, Croce CM, Gissmann L, Schwarz E, Huebner K Papillomavirus sequences integrate near cellular oncogenes in some cervical carcinomas. Proc Natl Acad Sci USA 1987, 84: $1070-4$. 